\title{
Prevalence of new psychoactive substances addiction: a hospital-based cross-sectional study
}

\author{
Mariya Prilutskaya' $^{1}$, Oleg Yussopov², Nikolay Negay ${ }^{3}$, Kuanysh Altynbekov ${ }^{3}$, Makpal Tokayeva1
}

${ }^{1}$ Department of Personalized Medicine and Pediatrics, Pavlodar Branch of Semey Medical University, Pavlodar, Republic of Kazakhstan

${ }^{2}$ Epidemiology Department, Monitoring Center on Alcohol and Drugs, Pavlodar, Republic of Kazakhstan ${ }^{3}$ Scientific and Clinical Department, Republican Scientific and Practical Center of Mental Health, Director, Almaty, Republic of Kazakhstan

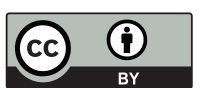

This work is licensed under a Creative Commons Attribution 4.0 International License

Received: 2020-01-20

Accepted: 2020-02-09

UDC: 618.1

\section{J Clin Med Kaz 2020; 1(55):11-16}

Corresponding Author: Mariya Prilutskaya, PhD, assistant, Department of Personalized Medicine and Pediatrics, Pavlodar Branch of Semey Medical University. Address: 83 Torajghyrov str, apt 39, 140002 Pavlodar, Republic of Kazakhstan.

Tel.: +77014186539, 87182552854

E-mail: mariyapril2407@gmail.com
Abstract

Background: New psychoactive substances are a combined group of chemical substances developed in an attempt to circumvent control and restrictive measures for traditional drugs. Until 2017, the countries of Central Asia remained a gray spot on the maps of epidemiological new psychoactive substances reports. The largest share of new psychoactive substances on the Kazakhstani market became of a serious concern for both the law enforcement authorities and the public health services during the last five years.

Objectives: The aim of the study was to assess the proportion of hospitalizations in Kazakhstan related to new psychoactive substances addiction over a three-year period (2016-2018) and to describe the patterns of new psychoactive substances use in the sample of admitted patients.

Material and methods: This study was a retrospective, cross-sectional investigation using regional databases consisting of the 2018 cases of hospitalizations at 16 state regional mental treatment centers and 3 state narcological clinics across Kazakhstan. We analyzed 345 cases of NPS addiction.

Results: The proportion of admitted in 2018 new psychoactive substances patients amounted to $10.01 \%(9.1 \% ; 11.1 \%)$, comprising an ascending trend since 2016. The highest prevalence of the new psychoactive substances addiction was registered in Nur-Sultan, Almaty cities, and North-Kazakhstan region. Cathinones prevailed over other NPS groups (71.9\%) and were mostly used in parallel with traditional opioids. Synthetic cannabinoids $(28.1 \%)$ were associated with herbal cannabis use in three quarters of cases; smoking absolutely prevailed as the main route of their administration.

Conclusion: This study suggests that new psychoactive substances addiction is a current clinical phenomenon, which should be reflected in the development and revision of the national drug treatment programs across Kazakhstan. The disparity of new psychoactive substances prevalence in the regions should be considered in the development of local anti-drug plans by the health care service and law enforcement authorities.

Key words: new psychoactive substances, prevalence, addiction, hospital, pattern

\section{ЖАНА ПСИХОБЕЛСЕНДІ ЗАТТАРҒА ТӘУЕЛДІЛІКТІҢ ТАРАЛУЫ: ГОСПИТАЛЬДІК КРОСС-СЕКЦИЯЛЫҚ ЗЕРТTЕУ}

М. Прилуцкая ${ }^{1}$, О. Юсопов ${ }^{2}$, Н. Негай ${ }^{3}$, К. Алтынбеков ${ }^{3}$, М. Тоқаева $^{1}$

'Дербестендірілген және педиатрия кафедрасы, «Семей медицина Университеті» коммерциялық емес акционерлік қоғамының Павлодар филиалы, Павлодар қаласы, Қазақстан Республикасы

Эпидемиологиялық бөлімі, Алкоголь және есірткі мониторингі орталығы, Павлодар қаласы, Қазақстан Республикасы

${ }^{3}$ Клиникалық және ғылыми бөлімі, Республикалық психикалық денсаулық ғылыми-практикалық орталығы, Алматы қаласы, Қазақстан Республикасы

Кіріспе: Жаңа психобелсенді заттар - бұл дәстүрлі есірткілерге қатысты қабылданған бақылау және тежейтін шаралардан жалтаруға әрекет ету үшін әзірленген химиялық субстанциялардың құрама тобы. 2017 жылға дейін Орталық Азия елдері жаңа психобелсенді заттар мәселесін бейнелейтін эпидемиологиялық карталарда сұр дақ болып көрініс берді. Қазақстанның өңіріндегі заңсыз нарығына келетін ЖПЗ ең көп үлесі құқық қорғау құрылымдары үшін де, қоғамдық денсаулық сақтау жүйесі үшін де алаңдаушылықты туғызады. 
Мақсаты: Осы зерттеудің мақсаты үш жылдық кезең ішінде (2016-2018 жылдар) жаңа психобелсенді заттар тәуелділігіне байланысты қазақстандық емдеуге жатқызу пропорциясын бағалауда және емделген пациенттерді таңдауда жаңа психобелсенді заттар тұтыну паттерналарының сипаттамасында болды.

Материалдар мен әдістер: Біздің зерттеу 16 аймақтық психикалық денсаулық орталығында және 3 наркологиялық клиникада емдеуге жатқызу бойынша статистикалық базаларды пайдалана отырып, ретроспективті, кросс-секциялық болды. Барлығы жаңа психобелсенді заттар туындаған тәуелділділіктің 345 жағдайы талданды.

Нәтижелері: ЖПЗ тәуелді емдеуге жатқызылған пациенттердің пропорциясы 2018 жылы 10,01\% (9,1; 11,1) құрады. Жаңа психобелсенді заттар тәуелді емдеуге жатқызудың ең жоғары таралуы Солтүстік Қазақстан облысы, Нұр-сұлтан және Алматы қалаларында тіркелген. Катинондар жаңа психобелсенді заттар (71,9\%) басқа топтарының арасында басым болды және дәстүрлі опиоидтармен қатар жиі қолданылды. Синтетикалық каннабиноидтар $(28,1 \%)$ үшінші жағдайда өсімдік каннабисімен байланыстырылды; абсолютті түрде темекі шегу осы заттарды қабылдаудың негізгі тәсілі ретінде басым болды.

қорытынды: Біздің зерттеу жаңа психобелсенді заттар пайда болған тәуелділік бүкіл Қазақстан бойынша емдеу бағдарламалары үшін өзекті заманауи клиникалық феномен екенін көрсетті. Қазақстанның нақты қалалары мен облыстарында құқық қорғау органдары мен қоғамдық денсаулық қызметі есірткіге қарсы жоспарлар мен бағдарламаларды әзірлеу кезінде жаңа психобелсенді заттар таралуындағы өңірлік айырмашылықтар ескерілуі тиіс.

Негізгі сөздер: жаңа психобелсенді заттар, таралуы, тәуелділік, госпиталь, паттер

\section{РАСПРОСТРАНЁННОСТЬ ЗАВИСИМОСТИ ОТ НОВЫХ ПСИХОАКТИВНЫХ ВЕЩЕСТВ: ГОСПИТАЛЬНОЕ КРОСС- СЕКЦИОННОЕ ИССЛЕДОВАНИЕ}

М. Прилуцкая ${ }^{1}$, О. Юсопов ${ }^{2}$, Н. Негай ${ }^{3}$, К. Алтынбеков ${ }^{3}$, М. Токаева $^{1}$

${ }^{1}$ Кафедра персонализированной медицины и педиатрии, Павлодарский филиал НАО «Медицинский университет Семей», город Павлодар, Республика Казахстан

${ }^{2}$ Отдел эпидемиологии, Центр мониторинга за алкоголем и наркотиками, город Павлодар, Республика Казахстан

${ }^{3}$ Научный и клинический блок, Республиканский научно-практический центр психического здоровья, город Алматы, Республика Казахстан

\section{PEЗЮME}

Введение: Новые психоактивные вещества - это комбинированная группа химических субстанций, разработанных для попытки уклонения от контрольных и сдерживающих мер, принятых в отношении традиционных наркотиков. До 2017 года страны Центральной Азии представляли собой серое пятно на эпидемиологических картах, иллюстрирующих проблему новых психоактивных веществ. Наибольшая доля новых психоактивных веществ, приходящаяся на нелегальные рынки Казахстана в регионе представляет собой предмет для озабоченности как для правоохранительных структур, так и для системы общественного здравоохранения.

Цель: Цель настоящего исследования состояла в оценке пропорций казахстанских госпитализаций по поводу зависимости от новых психоактивных веществ за трёхлетний период (2016-2018 годы) и в описании паттернов потребления новых психоактивных веществ в выборке пролеченных пациентов.

Материалы и методы: Наше исследование было ретроспективным, кросс-секционным с использованием статистических баз по госпитализациям в 16 региональных центрах психического здоровья и 3 наркологических клиниках. Всего проанализировано 345 случаев зависимости от новых психоактивных веществ.

Результаты: Пропорция госпитализированных с зависимостью от новых психоактивных веществ пациентов составила в 2018 году $10,01 \%(9,1 ; 11,1)$, демонстрируя восходящий тренд с 2016 года. Наиболее высокая распространённость госпитализаций с зависимостью от новых психоактивных веществ зарегистрирована в городах Нур-Султан и Алматы, Северо-Казахстанской области. Катиноны превалировали среди других групп НПВ $(71,9 \%)$ и чаще использовались параллельно с традиционными опиоидами. Синтетические каннабиноиды $(28,1 \%)$ ассоциировались с растительным каннабисом в трети случаев; курение в абсолютном числе превалировало как основной способ приёма данных веществ.

Заключение: Наше исследование показало, что зависимость от новых психоактивных веществ представляет современный клинический феномен, актуальный для лечебных программ по всему Казахстану. Региональные различия в распространённости новых психоактивных веществ должны быть учтены при разработке антинаркотических планов и программ правоохранительными органами и службой общественного здоровья в конкретных городах и областях Казахстана.

Ключевые слова: новые психоактивные вещества, распространённость, зависимость, стационар, паттерн

\section{Introduction}

New psychoactive substances (NPS) are a combined group of chemical substances that have been developed in an attempt to circumvent control and restrictive measures for traditional drugs. Initially, NPS were distributed as legal analogues of illegal narcotic stimulants and hallucinogens, gradually moving to the list of prohibited psychoactive substances in connection with the strengthening of legislative control around the world.

According to the United Nations Office on Drugs and Crime (UNODC) World Drug Report, 892 different substances have been newly reported in addition to the traditionally scheduling narcotics over the last decade [1].

Understanding this new phenomenon in society for the development of appropriate decisions and measures emphasizes the relevance of the epidemiological studies of the NPS use prevalence among the population and the NPS market. Difficulties in the analysis of the prevalence of the NPS problems are caused by significance of NPS identification requirements for laboratories. Barriers in assessing the prevalence of NPS consumption are generated by the lack of standardized monitoring algorithms both among the general population and among vulnerable groups. The epidemiological information is currently being accumulated separately at the country level and within sporadic regional studies.

Until 2017, the countries of Central Asia remained a gray spot on the maps of international epidemiological NPS reports. The first official information became available in UNODC drug report on the regional market of synthetic narcotics in December 2017. According to this document, in Central Asian countries there has been a significant increase in the number of identified NPS: from 1 in 2013 to 49 in 2016 [2].

The largest share of NPS on the Kazakhstani market is of a serious concern for both the law enforcement authorities and the public health service. This fact is exacerbated by poor standard monitoring procedures addressing NPS prevalence and an absence of comprehensive assessment of their harms in the given country [3].

The only pilot study to assess the proportion of Kazakhstani NPS consumers among drug addiction patients was conducted in 2017, which showed a NPS prevalence of $1-2 \%$ throughout the country with wholly disproportionate distribution of the indicator among different regions. As an illustration, state drug addiction clinics in the western regions (Aktau and Atyrau) did not admit any NPS patients, whereas in the northern regions 
(Petropavlovsk, Pavlodar) up to three quarters of drug addiction patients demonstrated symptoms of NPS abuse [4]. The pilot results notwithstanding, the regular analysis of hospitalizations related to NPS abuse and NPS addiction is far cry from an implementation into the public health practice.

Both the discrepancy and shortage highlight the importance of the regular monitoring of NPS prevalence in the nation-wide sample of drug-addicted patients. The indicator, as one of the few available, helps implicitly estimate the number of NPS consumers in the country and forecast the extension of NPS demands in illegal local narcotic markets.

Addressing aforementioned challenges, this study investigated the proportion of hospitalizations related to NPS addiction including cases with psychotic complications in anamnesis. The study had two specific aims: firstly, to identify the regional structure of NPS-related hospitalizations in the context over a three-year period; and secondly, to describe the patterns of NPS use in the sample of admitted patients.

\section{Material and methods}

Our study was conducted at 16 state regional mental treatment centers and three narcological clinics (Pavlodar Branch Of Republican Scientific And Practical Center Of Mental Health, Nur-Sultan Drug Addiction And Psychotherapy Center, Karaganda Drug Addiction Dispensary), which admit patients with symptoms of chemical addiction for detoxification and rehabilitation. This was a retrospective, cross-sectional study using databases consisting of the 2018 cases of hospitalizations at the given clinics and treatment centers. Considering the regional heterogeneity in the functioning of databases, we developed a standard research form to extract particular data related only to patients with NPS addiction: sex, age, ethnicity, education, occupation, concurrent clinical diagnoses, primary and secondary drugs of abuse, duration and frequency of NPS abuse, ways of NPS administration, history of psychotic complications. Trained specialists completed the forms only for those cases that presented with NPS addiction or NPS abuse diagnosed in accordance with related criteria of the rubrics of the International Classification of Diseases the 10-th version (ICD10) - "F11-19". Treatment records were checked by 19 specialists to confirm the history of NPS use as the only inclusion criterion for the study and to exclude cases of the repeated hospitalization in the given year. After applying inclusion and exclusion criteria, we analyzed 345 cases of NPS addiction.

The primary endpoints of this study were the distribution of the main demographic variables and the regional proportion of subjects admitted to the state mental hospitals due to NPS problems. The secondary endpoints of this study included patterns of NPS use and anamnestic pathways toward NPS addiction.

\section{Statistical analysis}

Statistical analysis was based on descriptive and comparative statistical methods. Descriptive data were presented as frequency in absolute numbers (n) and percentages for categorical variables (\%), as well as mean and standard deviation for numerical variables. Data comparisons were provided with the Mann-Whitney test (U) and the Wilcoxon test (W) for numerical variables, along with the Chi-Square test ( $\square 2$ ) for categorical variables. The level of significance was set at $\mathrm{p}$-value $(\mathrm{p})<0.05$. Crude risk ratio was calculated with a $95 \%$ confidence interval $(95 \% \mathrm{CI})$ to verify connection between social characteristics and treatment indicators. Graphical presentation was used to describe data in percentages and 95\% CI. All analytical procedures were performed with the Statistical Package for the Social Sciences (Version 20.0, SPSS Inc., Chicago, IL, USA).

\section{Ethical considerations}

The protocol of the study was approved by the Independent Ethics Committee of National Medical University as part of the reviewing of the grant application "Epidemiological portrait of NPS in the Republic of Kazakhstan: investigational epidemiologic study (EPI-NPS-KZ)" (27.03.2019, No.4(81)).

\section{Results}

The study sample was mostly males: 285 patients with NPS addiction (82.6\%). Age ranged between 15 and 60 years old. The main demographic characteristics by gender are summarized in Table 1. Compared to males, female patients were more often under 25 years old, of Russian ethnicity.

Demographic characteristics of patients with NPS addiction by gender

\begin{tabular}{|c|c|c|c|c|}
\hline & Whole sample $(n=345)$ & Females $(\mathrm{n}=59)$ & Males $(\mathrm{n}=285)$ & Statistical criterion*, p-value \\
\hline \multicolumn{5}{|l|}{ Age } \\
\hline Mean \pm standard deviation & $29.17 \pm 7.31$ & $27.68 \pm 6.87$ & $29.43 \pm 7.36$ & $\mathrm{U}=7203, \mathrm{p}=0.08$ \\
\hline Under 25 year old, n (\%) & $94(27.25 \%)$ & $23(38.98 \%)$ & $71(24.91 \%)$ & $\chi^{2}=4.86, p=0.03$ \\
\hline \multicolumn{5}{|l|}{ Ethnicity } \\
\hline Kazakhs & $103(29.86 \%)$ & $13(22.03 \%)$ & $90(31.58 \%)$ & $\chi^{2}=7.33, p=0.03$ \\
\hline Russians & $180(52.17 \%)$ & $40(67.79 \%)$ & $139(48.77 \%)$ & \\
\hline Others & $62(17.97 \%)$ & $6(10.17 \%)$ & $56(19.65 \%)$ & \\
\hline \multicolumn{5}{|l|}{ Education } \\
\hline Secondary school & $302(88.54 \%)$ & $51(86.44 \%)$ & $250(87.72 \%)$ & $\chi^{2}=0.07, p=0.78$ \\
\hline Higher education & $43(12.46 \%)$ & $8(13.56 \%)$ & $35(12.28 \%)$ & \\
\hline \multicolumn{5}{|l|}{ Employment } \\
\hline Unemployed & $319(92.46 \%)$ & $55(93.22 \%)$ & $263(92.28 \%)$ & $\chi^{2}=0.06, p=0.8$ \\
\hline
\end{tabular}

* Comparison between gender subgroups

$\mathrm{n}$ - absolute number, \% - percentage, $\mathrm{U}$ - the Mann-Whitney test, $\mathrm{p}$ - significance of the test, $\chi^{2}-$ the Pearson test 
Formal clinical diagnoses related to the following ICD10 rubrics: "F12" formulated in 78 cases $(22.6 \%)$, "F15" in 191 cases $(55.4 \%)$, "F19" in 71 cases $(20.6 \%)$. We identified significant differences in the proportion of particular NPS addiction in the regard to gender. Synthetic cannabinoid addiction were diagnosed in 76 male patients $(26.7 \%)$ versus two females (3.4\%) - $\square 2=15.7, \mathrm{p}<0.001$. In contrast, the proportion of NPS admissions with synthetic cathinone addiction in women $(\mathrm{n}=44$, $74.57 \%)$ was 1.5 higher than that of men $(n=147,51.57 \%)$ - $\square 2=10.44, \mathrm{p}=0.001$. Formal diagnosis of "F12" correlated with younger age (under 25 years old) $-\mathrm{RR}=1.58(1.07 ; 2.34)$, $\mathrm{p}=0.03$. Polysubstance addiction " $\mathrm{F} 19$ " prevailed in the older subgroup $-\mathrm{RR}=1.84$ (1.04; 3.27), $\mathrm{p}=0.04$.

Anamnestic self-reports on the use of particular NPS corresponded to the clinical diagnoses. Three quarters of the analyzed cases related to synthetic stimulant misuse - 248 $(71.88 \%)$ that demonstrated the aforementioned correlation with age and sex.

The chemical verification of NPS group was provided only for one in fourteen patients. Hence, ICD-10 diagnostic procedures were based exclusively on clinical implications and anamnestic information. Self-reported cases of NPS use were described in slang: "scorost", "krissy", "pivik", "meph", "spicy".

We calculated the proportion of NPS addiction in relation to the number of hospitalizations with abuse of any psychoactive substances except alcohol. In 2018 among all patients with substance use disorders, the NPS proportion amounted to $10.01 \%$ (95\% CI: $9.1 \%$; 11.1\%). Comparing the national rate in the given period with those of 2016 and 2017, an ascending trend in the number of NPS hospitalization was observed: in $2016-3.91 \%(3.2 \% ; 4.7 \%)$, in $2017-8.23$ (7.3\%; 9.2\%). Figure 1 summarizes the regional distribution of NPS hospitalizations over three years.

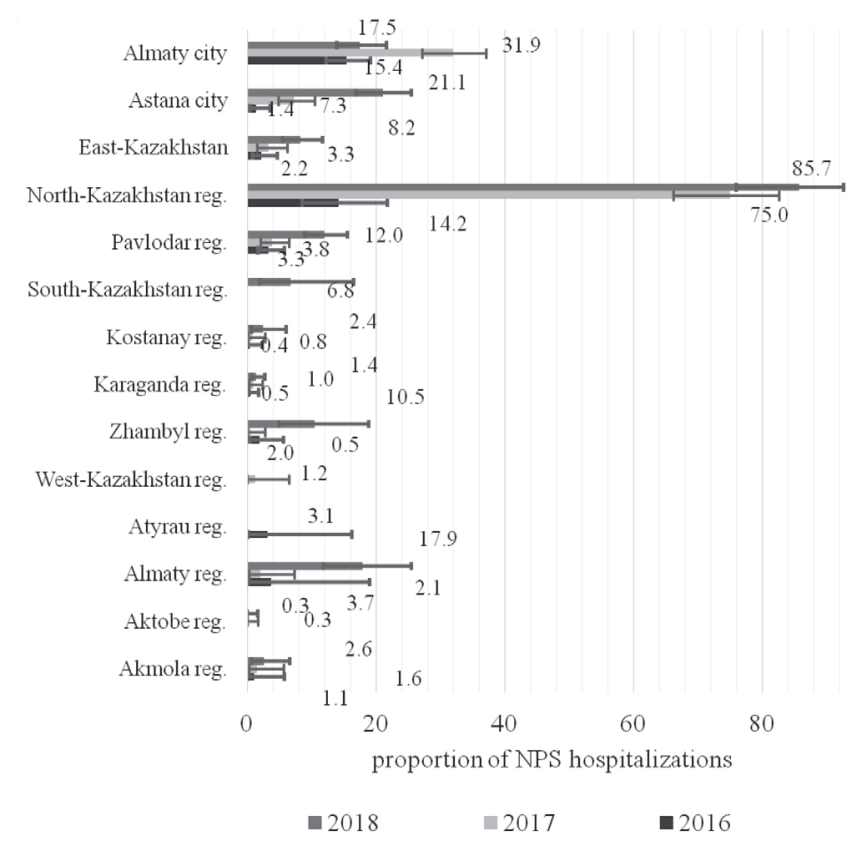

Figure 1

In 2018, cathinones were registered as the most prevalent NPS group in Astana and Almaty cities, Akmola, Karaganda, Kostanay, and East-Kazakhstan regions. Pavlodar, NorthKazakhstan and South-Kazakhstan regions revealed an equal popularity of synthetic cathinones and cannabinoids. The latter NPS group was dominant in Almaty and Aktobe regions.

Synthetic cathinones and non-specified amphetamine-type stimulants $(71.9 \%, \mathrm{n}=248)$ prevailed over other NPS groups and were mostly used in parallel with traditional opioids $-20.87 \%$ $(n=72)$. One-third part of stimulant users reported parenteral routes of drug administration. Synthetic cannabinoids (28.1\%, $\mathrm{n}=97)$ were associated with herbal cannabis use in three quarters of cases. Smoking absolutely prevailed as the main route of administration for "spices".

Analyzing anamnestic characteristics of NPS use, we identified the main pathways of NPS dependency development. Figure 2 displays the sequences of the first NPS probes in the context of traditional drug use.

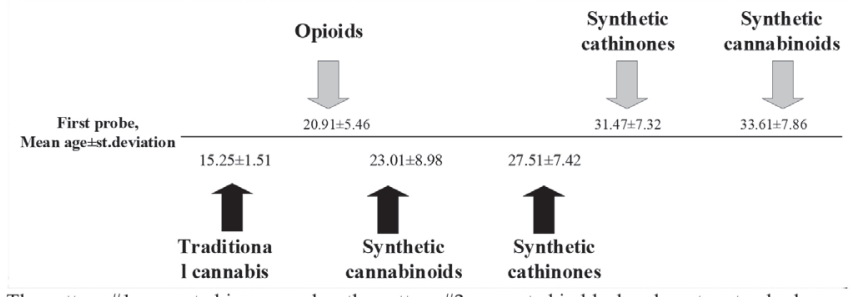

The pattern \#1 presented in grey color, the pattern \#2 presented in black color, st. - standard

\section{Figure 2}

Two patterns of polydrug pathways were observed among the given cases. According to the first variant, switching to synthetic cathinones was registered after a 5-10-year period of heroin dependency and followed by sporadic episodes of synthetic cannabinoid use within 2-3 years. In the alternative variant, herbal cannabis appeared to be the initial psychoactive substance transforming into intensive synthetic cannabinoids use with regular cathinone experiments.

Aside from the onset of a dependency syndrome, other characteristics of NPS use did not reveal statistically significant differences between cathinones and cannabinoids (Table 2).

Table 2 Quality characteristics of the use of synthetic cannabinoids and cathinones

\begin{tabular}{|l|l|l|l|l|}
\hline Characteristics & $\begin{array}{l}\text { Synthetic } \\
\text { cannabinoids } \\
\text { (n=109), } \\
\text { mean } \pm \text { st. dev. }\end{array}$ & $\begin{array}{l}\text { Synthetic } \\
\text { cathinones, } \\
\text { (n=257) } \\
\text { mean } \pm \text { st. } \\
\text { dev. }\end{array}$ & W, p-value \\
\hline Age & $\begin{array}{l}\text { First episode } \\
\text { of use }\end{array}$ & $23.27 \pm 7.43$ & $26.84 \pm 6.87$ & $1.8,0.07$ \\
\hline $\begin{array}{l}\text { Onset of the } \\
\text { dependency } \\
\text { syndrome }\end{array}$ & $23.9 \pm 7.56$ & $27.2 \pm 6.56$ & $2.1,0.03$ \\
\hline Daily dose & $1.02 \pm 0.94$ & $0.77 \pm 0.69$ & $0.7,0.48$ & \\
\hline $\begin{array}{l}\text { Daily } \\
\text { frequency of } \\
\text { NPS use }\end{array}$ & $3.49 \pm 2.47$ & $3.35 \pm 2.87$ & $0.59,0.56$ & \\
\hline $\begin{array}{l}\text { Weekly rhythm } \\
\text { of NPS use }\end{array}$ & $4.62 \pm 2.27$ & $5.47 \pm 2.23$ & $1.08,0.28$ & \\
\hline
\end{tabular}

One in five admissions in the study was caused by psychotic symptoms: for synthetic cathinones, the rate was significantly higher $(24.7 \%, n=61)$ compared with other NPS $(5.6 \%, n=4)$. A half of those with current psychoses experienced up to two delusional and hallucinatory episodes in anamnesis.

\section{Discussion}

A vast majority of current publications focus their attention on acute effects of NPS intoxication and report more than 150 side effects caused by hundreds of toxic substances [5]. In addition, media reports shed lights on the most drastic cases of NPS abuse complications such as cardiac arrests, psychotic outbreaks, epileptic seizures and aggressive behavior 
[6]. In this regard, law enforcement authorities develop a broad range of controlling measures to alleviate NPS situation. As a result, experts register regular changes within illegal markets and continuous transformation of NPS user profiles. Initially supposed to substitute illegal narcotics, NPS have become associated with severe addiction symptoms and disruptive social negligence exceeding those of traditional drugs.

Patients with the NPS abuse and the NPS addiction constitute a vulnerable group underrepresented in medical programs and rehabilitation facilities all over the world. Meanwhile, serious side effects associated with NPS use warrant the broader utilization of evidence-based medical and psychosocial interventions for this group of population. Poor treatment compliance and low therapeutic retention limit the NPS patient capacities for complete remission and successful social adaptation [7].

The high-risk NPS use is widely regarded by a number of international boards as a modern phenomenon that absolutely needs to be subjected to thorough examination and scrutiny. According EMCDDA, the term high-risk NPS use covers the following conditions: combination of NPS and traditional drugs, injection of NPS, presence of socially marginalized background and concurrent mental health problems [8].

For the first time in Central Asia, according to available information, our study investigated the patterns of the highrisk NPS use in a hospital-based sample. We revealed that in $42.03 \%(n=145)$ of cases NPS addiction was accompanied by traditional drug abuse. Patients reported the combination of synthetic cathinones with traditional opioids in a fifth of the cases $(20.87 \%)$, of synthetic cannabinoids in a third of the cases (28.1\%). One-third part of stimulant users reported parenteral routes of drug administration including slamming, referred to in Russian as "marafony".

In the present study we found that the prevalence of NPS addiction in drug using patients fluctuated among different regions, nationally comprising $10.01 \%$ (95\% CI: 9.1\%; $11.1 \%)$ of all substance use disorders except alcohol. The ascending three-year trend implicitly indicates the serious social and legal implications of the NPS emergence to consider and examine. The present results highlight the significance of this issue for public health, indicating the regions where NPS problems pose serious concern. We explain it as a result of the drastic penetration of new synthetic narcotics into the local markets from neighboring Russia and China. This assumption corresponds with the stable exponential growth of NPS hospitalizations in Pavlodar, NorthKazakhstan regions and Almaty city. Various social, legal and economic factors may contribute to the recent peak of NPS admissions in Nur-Sultan (Astana) city, such as tight restriction and consequential shortage of traditional narcotics on the illegal markets, larger young population, the role of state hub. Recently, an increasing number of epidemiological studies have shown that the NPS prevalence correlates with the effectiveness of legal prohibition systems. According to the world statistical data, the NPS prevalence in psychiatric or drug addiction clinics ranges between 10 and $30 \%$ related to the severity of NPS restriction [9].

In Kazakhstan, the legal system of NPS scheduling has developed over the nine-year period resulting in the prohibition of more than 100 harmful substances. In parallel, the government has established a procedure for the rapid banning of any other newly emerged drugs from the July of 2019 [10]. In light of these facts, we expect a substantial change in the 2019 NPS prevalence that justifies our interest in further investigation.

Our finding revealed some distinctions in social profile of the NPS patients, compared to analogous studies with hospital-based samples. The sample of Kazakhstani NPS patients is distinct in that younger, has a higher rate of male unemployment. This may indicate the extreme vulnerability of the nation youth population that has become more exposed to the NPS emergency. Universal gender barriers in all drug treatment systems may explain the low proportion of women in hospital samples that was also observed in our study. The rate of psychotic complications in our sample corresponds with the international level of $30 \%$ and reflects the need for more robust emergency care addressing NPS poisoning and intoxication. The observed NPS use patterns indicated the high frequency of daily narcotization episodes along with variable NPS dosages in our patients that agree with the findings reported by Stanley and Subeliani [11, 12]. The short period between the first episode of NPS use and addiction onset demonstrated the rapid development of the NPS dependency syndrome and is consistent with previous literature data on destructive nature of synthetic drugs $[13,14]$.

Undertaking subgroup comparisons, we revealed that synthetic cannabinoids and cathinones differed with respect to ways of drug administration. Synthetic cannabinoids were smoked in cigarettes mixed with plants (peppermint and chamomile) or vaporized through bongs (in slang bombaster). Similar to the data of other studies (Stanley, Karila) [11, 15], most of our patients reported various ways of synthetic cathinone administration, including the high-risk parenteral $(n=79$, $30.73 \%)$. Thus, all the identified cases of HIV ( $n=30,8.69 \%)$ and viral hepatitis $(n=61,17.68 \%)$ were related to stimulant drug use.

Analyzing polydrug use, we identified two main patterns of switching from traditional drugs to NPS. Primary opioid addiction was substantially associated with synthetic cathinone abuse; synthetic cannabinoids were more popular among natural cannabis users. The distinct pathways may be related to the observation of two different patient cohorts: older high-risk opioid users and younger low-risk marijuana users. Our findings complements international reports on different patterns of NPS use in diverse social groups: Kapitány-Fövény underlines the role of synthetic cathinones as substitutes in the event of opioid shortage [16], several surveys in thousands young adults confirm the higher popularity of synthetic cannabinoids $[17,18]$.

The revealed low rate of laboratory-identified NPS cases is a matter of considerable concern. Less reliable self-reports of patient and non-specified immunoassay tests are the only confirmation of NPS addictions for the state clinics. Meanwhile, a range of sources underlines the importance of advanced massspectral laboratories in the provision of toxicological information on the most complicated clinical NPS cases for the public health service $[19,20]$. In our study, shortage of exact chemical data may limit accuracy of the NPS prevalence calculation and preciseness of subgroup analysis on the use patterns.

The present study involved several other limitations that should be considered. First, our data collection was conducted retrospectively, relying only on medical records retrieved from heterogeneous databases. Thus, the obtained information would be expected to be less factual than that of prospective studies, especially considering some present findings related to NPS addictions pathways. Local discrepancies of rehabilitation programs limited our interpretations regarding the real reasons behind the revealed regional disparity of medical service utilization in the given sample. Namely, Nur-Sultan along with Pavlodar and Karaganda regions are provided with highly developed rehabilitation centers that could attract more patients 
to the clinics, contributing to higher admissions including those with NPS addictions in the regions. Moreover, our design did not allow the comparison of social profiles of NPS and traditional drugs users to assess the likelihood of NPS use among different groups of chemical addicts. Finally, the prevalence of NPS addiction and NPS use patterns were assessed in the hospital-based sample, whereas unregistered NPS users remain unrepresented within the study scope. This fact limits the extent of the extrapolation of our results and underlines the necessity for future studies addressing NPS epidemiology in various social groups.

\section{Conclusion}

Results of our study suggest that NPS addiction is a current clinical phenomenon relevant to the national drug treatment programs across Kazakhstan. The ascending 3-year trend of NPS hospitalizations indicates the essential role of progressive treatment standards with advanced toxicological laboratories. The disparity of NPS prevalence in the regions should be considered in the development of local anti-drug plans by the public health care service and law enforcement authorities.

Disclosures: There is no conflict of interest for all authors.

Sponsor of the study: European Union, the CADAP 6 programme (DCI-ASIE/2015/356-893), component 2 - NFP. The component 2 was implemented by ResAd, s.r.o. (LLC), Prague, Czech Republic.

\section{References}

1. UNODC. February 2019 - UNODC-SMART: Almost 900 NPS reported to UNODC from 119 countries and territorieshttps://www. unodc.org/LSS/Announcement/Details/eff8dc38-7ab0-42b0-8cd9-753b89953fcc.

2. UNODC. Assessment of the situation with synthetic narcotics in Central Asia. Report of the Global SMART program. Vienna: UNODC typography. 31.

3. Prilutskaya MV, Molchanov SN. Assessment of needs in improvement of clinical competences on therapy of dependences from novel psychoactive substances in the Republic of Kazakhstan. J Clin Med Kaz. 2017; 43(1): 30-33. https://doi.org/10.23950/1812-2892JCMK-00383

4. Yussopov O, Kazakov V, Prilutskaya M et al. National Report on Drug situation in Republic of Kazakhstan. Prague: ResAd. $2019 ; 276$.

5. King LA, Corkery JM. An index of fatal toxicity for new psychoactive substances. J Psychopharmacol. 2018; 32(7):793-801. https:// doi.org/10.1177/0269881118754709

6. Adams AJ, Banister SD, Irizarry L, Trecki J, Schwartz M, Gerona R. "Zombie" Outbreak Caused by the Synthetic Cannabinoid AMBFUBINACA in New York. N Engl J Med. 2017; 376(3):235-242. https://doi.org/10.1056/NEJMoa1610300

7. Shalit N, Barzilay R, Shoval G, et al. Characteristics of Synthetic Cannabinoid and Cannabis Users Admitted to a Psychiatric Hospital: A Comparative Study. J Clin Psychiatry. 2016; 77(8):e989-e995. https://doi.org/10.4088/JCP.15m09938

8. EMCDDA. High-risk drug use and new psychoactive substances. Rapid Communication. Luxembourg: Publications Office of the European Union, 2017; 21.

9. Pettie J, Burt A, Knipe DW, et al. New drug controls and reduced hospital presentations due to novel psychoactive substances in Edinburgh. Br J Clin Pharmacol. 2018; 84(10):2303-2310. https://doi.org/10.1111/bcp.13672

10. Law of the Republic of Kazakhstan. About amendments and additions to some legislative acts of the Republic of Kazakhstan on drug control issues, psychotropic substances, their analogues and precursors [in Russian]. 2018; https://online.zakon.kz/document/?doc id=38951688 Accessed January 17, 2020.

11. Stanley JL, Mogford DV, Lawrence RJ, Lawrie SM. Use of novel psychoactive substances by inpatients on general adult psychiatric wards. BMJ Open. 2016; 6(5):e009430. https://doi.org/10.1136/bmjopen-2015-009430

12. Subeliani D, Otiashvili D, Kutelia L, et al. Patterns of use of new psychoactive substances and perceived benefits and negative effects: results of online survey in Georgia (country). Journal of Substance Use. 2019; https://doi.org/10.1080/14659891.2019.1692927

13. Cooper ZD. Adverse Effects of Synthetic Cannabinoids: Management of Acute Toxicity and Withdrawal. Curr Psychiatry Rep. 2016; 18(5):52. https://doi.org/10.1007/s11920-016-0694-1

14. Banks ML, Worst TJ, Rusyniak DE, Sprague JE. Synthetic cathinones ("bath salts"). J Emerg Med. 2014; 46(5):632-642. https://doi. org/10.1016/j.jemermed.2013.11.104

15. Karila L, Megarbane B, Cottencin O, Lejoyeux M. Synthetic cathinones: a new public health problem. Curr Neuropharmacol. 2015; 13(1):12-20. https://doi.org/10.2174/1570159X13666141210224137

16. Kapitány-Fövény M, Farkas J, Pataki PA, et al. Novel psychoactive substance use among treatment-seeking opiate users: The role of life events and psychiatric symptoms. Hum Psychopharmacol. 2017; 32(3):10. https://doi.org/10.1002/hup.2602

17. Caviness CM, Tzilos G, Anderson BJ, Stein MD. Synthetic Cannabinoids: Use and Predictors in a Community Sample of Young Adults. Subst Abus. 2015; 36(3):368-373. https://doi.org/10.1080/08897077.2014.959151

18. Gunderson EW, Haughey HM, Ait-Daoud N, Joshi AS, Hart CL. A survey of synthetic cannabinoid consumption by current cannabis users. Subst Abus. 2014; 35(2):184-189. https://doi.org/10.1080/08897077.2013.846288

19. Vallersnes OM, Persett PS, Øiestad EL, Karinen R, Heyerdahl F, Hovda KE. Underestimated impact of novel psychoactive substances: laboratory confirmation of recreational drug toxicity in Oslo, Norway. Clin Toxicol (Phila). 2017; 55(7):636-644. https://doi.org/10.10 80/15563650.2017.1312002

20. Dines AM, Wood DM, Yates C, et al. Acute recreational drug and new psychoactive substance toxicity in Europe: 12 months data collection from the European Drug Emergencies Network (Euro-DEN). Clin Toxicol (Phila). 2015; 53(9):930. https://doi.org/10.3109 $/ 15563650.2015 .1088157$

How to cite this article: Mariya Prilutskaya, Oleg Yussopov, Nikolay Negay, Kuanysh Altynbekov, Makpal Tokayeva. Prevalence of new psychoactive substances addiction: a hospital-based cross-sectional study. J Clin Med Kaz. 2020; 1(55):11-16 